\title{
Optimization of Process Parameters for Cellulase Production by Bacillus licheniformis MTCC 429 using RSM and Molecular Characterization of Cellulase Gene
}

Bhaumik R Dave, Pritesh Parmar, Ankit Sudhir, Ketankumar Panchal and Subramanian RB*

BRD School of Biosciences, Sardar Patel Maidan, Satellite Campus, Sardar Patel University, Gujarat, India

\begin{abstract}
World is threaten to energy crisis which has advances research in bioenergy and specifically development of biofuels to replace petroleum products have increased the use of microbial enzyme like cellulases and xylanases as well as amylases for generation of reducing sugars for their conversion into bioethanol. Extensive research has been carried out in this view but alkaline cellulase production and molecular characterization is not studied in detail so far, this study will aid to achieve it. Optimization of fermentation parameters for production of cellulase was evaluated with the help of Response Surface Methodology (RSM) a statistical design, initial pH (9), moisture ratio (1:1) and incubation time $(72 \mathrm{~h})$ (run no.4) were found to be ideal parameters for optimum production of cellulase, substrate Jatropha seed cake without any pre-treatment was found to be an ideal source for cellulase production by Bacillus licheniformis under solid state fermentation. Cellulase gene of size $786 \mathrm{bp}$ was isolated later using PCR techniques, confirmed with sequence analysis and ligated to pRSET A vector for the transformation to $E$. coli DH5 $\alpha$. Positive clones were identified and sequenced to justify the cloning. Sequence of Bacillus licheniformis endo- $\beta-1,4$-glucanase (Cel12A) gene showed $100 \%$ similarity with endoglucanase gene sequence from Bacillus licheniformis ATCC 14580 genome, shows successful cloning of Cel12A gene into pRSET A vector.
\end{abstract}

Keywords: Cellulase; Cloning; Isolation; Production

\section{Introduction}

Among various bacterial genera reported for production of various industrially important enzymes so far, Bacillus genus had widely been explored for production of various enzymes. The genus Bacillus established by Cohn in 1872, has undergone taxonomic changes. In the $2^{\text {nd }}$ edition of the taxonomic outline of Bergey's manual of Systematic Bacteriology [1,2] phylogenetic classification schemes, accomplished mainly by the analysis of $16 \mathrm{~S}$ rDNA sequence similarities were included in the family of Bacillaceae. The genus Bacillus is made up by 94 species. Bacillus species are historically clustered into six large groups based on numerous physiological, biochemical and morphological characters. The groups contain various Bacillus spp. which are described below:

Group I includes B. polymyxa as a reference organism, comprises facultative anaerobic species that ferment a variety of sugars and have reasonably fastidious growth requirements in the form of vitamins and amino acids. Numerous extracellular enzymes such as amylases, glucanases including cellulases, pectinases and pullulanases are secreted by members of this group.

Group II consists of B. subtilis and its relatives, B. amyloliquefaciens, B. licheniformis and B. pumilus. Some species such as B. anthracis, $B$. cereus, $B$. licheniformis and $B$. thuringiensis, secrete numerous extracellular enzymes including many commercially important amylases, $\beta$-glucanases and proteases.

Group III species are perhaps taxonomically the least defined and are rather physiologically heterogeneous. This group is based on Brevibacillus brevis which is a strict aerobe that does not produce appreciable acid from sugars and differentiates into an oval endospore that distends the sporangium. Other species in this group might include B. badius and " $B$. freudenreichii".

Group IV is a phylogenetically homogeneous group of species including B. sphaericus, the psychrophiles B. nsolitus, B. psychrophilus and some other species.
Group V is composed of the thermophilic bacilli, represented by $B$. stearothermophilus, as a separate group. This includes a physiologically and morphologically heterogeneous collection of species with various metabolic pathways.

Group VI, the acidophilic thermophiles have recently been allocated to the new genus Alicyclobacillus in which thermophily appears to have independently evolved in many lineages. Recent researches, based on a "pan-genomic" approach, support the division of Bacillus into further new genera and revealed unexpected groupings suggesting that the final picture of Bacillus taxonomy is still far from drawn [3,4]. Bacillus species are an important source of insecticides, antibiotics, vitamins and enzymes [5].

Bacillus species have been major industrial workhorse industrial microorganisms with roles in microbiology, which have been used thousand years back, since the production of natto by solid-state fermentation of soyabeans using Bacillus subtilis. Natto was first practiced in Japan [6]. The role of Bacillus had continually expanded in the past century. Molecular biology techniques have contributed a lot for the development of strains and production strategies. Bacillus species are attractive industrial organisms for a variety of reasons, (1) High growth rates leading to short fermentation cycle times. (2) Capacity to

${ }^{*}$ Corresponding author: Subramanian RB, BRD School of Biosciences, Sardar Patel Maidan, Satellite Campus, Post Box No. 39, Sardar Patel University, Vallabh Vidyanagar 388 120, Gujarat, India, Tel: +91-2692-234-402; E-mail asp.fus@gmail.com

Received December 31, 2014; Accepted February 26, 2015; Published March 03, 2015

Citation: Dave BR, Parmar P, Sudhir A, Panchal K, Subramanian RB (2015) Optimization of Process Parameters for Cellulase Production by Bacillus licheniformis MTCC 429 using RSM and Molecular Characterization of Cellulase Gene. J Bioprocess Biotech 5: 212 doi: 10.4172/2155-9821.1000212

Copyright: $\odot 2015$ Dave BR, et al. This is an open-access article distributed under the terms of the Creative Commons Attribution License, which permits unrestricted use, distribution, and reproduction in any medium, provided the original author and source are credited. 
Citation: Dave BR, Parmar P, Sudhir A, Panchal K, Subramanian RB (2015) Optimization of Process Parameters for Cellulase Production by Bacillus licheniformis MTCC 429 using RSM and Molecular Characterization of Cellulase Gene. J Bioprocess Biotech 5: 212 doi: 10.4172/21559821.1000212

Page 2 of 9

secrete proteins into the extracellular medium and (3) GRAS (generally regarded as safe) status with the Food and Drug Administration for species, such as B. subtilis and Bacillus licheniformis [4]. At present there is enough information about the biochemistry, physiology, and genetics of B. subtilis, B. licheniformis and other species, which facilitates further development and greater exploitation of these organisms in industrial processes.

Moreover, Bacillus thuringiensis a member of genus Bacillus produces an endotoxin which has given a new era in the development of the BT plant varieties having defense mechanism against insect pests. One of the most popular examples is BT-cotton. This approach has helped farmers to get higher yields and more resistance towards the pests.

Bacillus subtilis and related Bacillus strains continue to be the dominant enzyme-producing microorganisms in industries. These organisms are an important source of industrial extracellular enzymes, including proteases and amylases. The world market for industrial enzymes is estimated to be 1.6 billion US\$, split between food enzymes (29\%), feed enzymes (15\%), and general technical enzymes (56\%) [7]. Most detergent proteases currently used in the market are serine proteases of Bacillus spp. [8]. It is estimated that enzymes of Bacillus spp. make up about $50 \%$ of the total enzyme market. Many researchers have studied various Bacillus spp. for production of extracellular enzymes like amylases, xylanases, proteases and cellulases using submerged or solid state fermentation technology [9-15].

Response surface methodology is applied to optimize and model the number of variable which leads to the optimization of process parameters with combination of experimental design by interpolation of first or second polynomial equation in systemic order [16]. It is a useful package which is being used worldwide successfully, integrates statistical approach to deduce the effect of multiple variables on the response with its preinformation about relationships amongst them $[17,18]$. As it is now being considered as the best statistical package to optimize the process parameters it was applied in the present study to obtain the better yield of the cellulase enzyme.

Recent advances in bioenergy research and specifically development of biofuels to replace petroleum products have increased the use of microbial enzyme like cellulases and xylanases as well as amylases for generation of reducing sugars for their conversion into bioethanol. B. licheniformis in biofuel research has been used in first generation biofuel technology. A thermostable $\alpha$-amylase from $B$. licheniformis has been used for the liquefaction of starch containing substrates like wheat flour and corn meal $[19,20]$. The hydrolysates obtained thus will further be converted into ethanol using yeasts like Saccharomyces cerevisiae. Second generation biofuel technology focuses on degradation of cellulosic plant biomass into reducing sugars for fermentation into bioethanol instead of hydrolysis of food materials like starch for fermentation into ethanol [21-23]. Hence second generation biofuels require better understanding of enzymes which can efficiently degrade plant cellulosic and hemicellulosic biomass into fermentable sugars.

There have, however, been several reports of hydrolytic enzymes contributing to hydrolysis of plant cell walls from various strains of $B$. licheniformis [24-38].

The study described in this chapter suggests the use of Bacillus licheniformis MTCC 429 for production of an endoglucanase under solid state fermentation using Jatropha deoiled seed cake as a substrate.
In addition amplification of the gene encoding alkaline cellulase from Bacillus licheniformis, its cloning and sequence analysis has also been carried out.

\section{Materials and Methods}

\section{Inoculum preparation and inoculation}

For the development of inoculum, culture was transferred from stock to $100 \mathrm{ml}$ nutrient broth and the inoculated flasks were incubated overnight at $37^{\circ} \mathrm{C}$ and $120 \mathrm{rpm}$. Cells were harvested from the broth and their absorbance $(A)$ was checked at $660 \mathrm{~nm}$. Accordingly, cells with inoculum size of $A 660=0.5$ ( $10 \%$ inoculum (volume per mass) per $5 \mathrm{~g}$ of substrate were harvested, washed and resuspended in sterile distilled water [10]. Inoculum thus prepared was used for solid state fermentation.

\section{Solid state fermentation}

Cellulase production was studied in flasks containing $5 \mathrm{~g}$ of Jatropha deoiled seed cake as a substrate. The basal medium used for cellulase production was $(\mathrm{g} / \mathrm{L})$, yeast extract (5), peptone (5), potassium dihydrogen phosphate (1), sodium chloride (5) and magnesium sulphate (0.2) [39]. The basal medium was sterilized at $121^{\circ} \mathrm{C}$ for $15 \mathrm{~min}$ at $15 \mathrm{lbs}$ pressure, allowed to cool and inoculated with $10 \%(\mathrm{v} / \mathrm{w})$ inoculum [13] The contents of the flasks were mixed thoroughly to ensure uniform distribution of the inoculum and incubated at $37^{\circ} \mathrm{C}$.

\section{Optimizaton of fermentation parameters by response surface methodology (RSM) using Box-Behnken Design (BBD)}

Bacterial culture: The bacterial culture Bacillus licheniformis MTCC 429 obtained from Microbial Type Culture Collection, IMTECH, Chandigarh, India, was subjected for cellulase production by solid state fermentation.

Substrate: Jatropha deoiled seed cake was obtained from biodiesel plant, Department of Bioenergy research, Anand Agriculture University, Anand, Gujarat.

Cellulase production by solid state fermentation: RSM using BBD was applied for optimization of cellulase production which involves full factorial search by observing simultaneous, systematic and efficient variation of important components on the fermentation process. Jatropha deoiled seed cake was selected as substrate for the optimization of cellulase production by response surface methodology. Three important parameters namely initial $\mathrm{pH}$ of the medium $\left(\mathrm{X}_{1}\right)$, moisture ratio $\left(\mathrm{X}_{2}\right)$ and incubation time $\left(\mathrm{X}_{3}\right)$ were selected as independent variables and the enzyme activity (cellulase $\mathrm{U} / \mathrm{g}$ ) was the dependent response variable. Each of these independent variables was studied at three different levels as per BBD in three variables with a total of 15 experimental runs. Cellulase activity (U/g) corresponding to the combined effects of three variables was studied in their specified ranges as shown in Table 1.

The temperature was kept constant at $37^{\circ} \mathrm{C}$ throughout the experiment. All the flasks were analyzed for cellulase activity at specific

\begin{tabular}{|l|c|c|c|}
\hline \multirow{2}{*}{ Process Variables } & \multicolumn{3}{|c|}{ Range and Level } \\
\cline { 2 - 4 } & $\mathbf{- 1}$ & $\mathbf{0}$ & $\mathbf{+ 1}$ \\
\hline Initial $\mathrm{pH}\left(\mathrm{X}_{1}\right)$ & 7.0 & 8.0 & 9.0 \\
\hline Moisture ratio $\left(\mathrm{X}_{2}\right)$ & $1: 0.5$ & $1: 1$ & $1: 1.5$ \\
\hline Incubation time $\left(\mathrm{X}_{3}\right)$ & $24 \mathrm{~h}$ & $48 \mathrm{~h}$ & $72 \mathrm{~h}$ \\
\hline
\end{tabular}

Table 1: Experimental range and coded levels of process variables for cellulase production. 
Citation: Dave BR, Parmar P, Sudhir A, Panchal K, Subramanian RB (2015) Optimization of Process Parameters for Cellulase Production by Bacillus licheniformis MTCC 429 using RSM and Molecular Characterization of Cellulase Gene. J Bioprocess Biotech 5: 212 doi: 10.4172/21559821.1000212

Page 3 of 9

\begin{tabular}{|c|c|c|c|}
\hline No. & Initial $\mathbf{p H}$ & Moisture ratio & Incubation time \\
\hline $\mathbf{1}$ & $\mathrm{X}_{1}$ & $\mathrm{X}_{2}$ & 0 \\
\hline $\mathbf{2}$ & 1 & -1 & 0 \\
\hline $\mathbf{3}$ & -1 & 0 & 0 \\
\hline $\mathbf{4}$ & 0 & 0 & 1 \\
\hline $\mathbf{5}$ & 1 & -1 & -1 \\
\hline $\mathbf{6}$ & 0 & 0 & -1 \\
\hline $\mathbf{7}$ & -1 & 0 & 0 \\
\hline $\mathbf{8}$ & 0 & 1 & 1 \\
\hline $\mathbf{9}$ & 0 & 0 & 1 \\
\hline $\mathbf{1 0}$ & -1 & 1 & 0 \\
\hline $\mathbf{1 1}$ & -1 & 1 & -1 \\
\hline $\mathbf{1 2}$ & 0 & 0 & 0 \\
\hline $\mathbf{1 3}$ & 0 & -1 & 1 \\
\hline $\mathbf{1 4}$ & 0 & 0 & -1 \\
\hline $\mathbf{1 5}$ & 1 & -1 & 0 \\
\hline
\end{tabular}

Table 2: Full factorial Box-Behnken Design for production of cellulase from Bacillus licheniformis.

time intervals as planned in BBD. The plan of BBD in the coded levels of the three independent variables is shown in Table 2.

For statistical calculations the levels of independent variables were coded as

$$
x_{i}=\left(X_{i}-X_{0}\right) / \delta X_{i}
$$

Where, $X_{i}$ is the actual value of variable; $X_{0}$ is the midpoint of the range of ;

$\delta X_{i}$ is the step change in $X_{i}$ and $x_{i}$ is the coded value for $X_{i}$ $, \mathrm{i}=1,2,3$.

Response surface methodology allows the modeling of a second order equation that describes the process. Cellulase production data was analyzed and response surface model given by Equation (5.2) was fitted with multiple regressions through the least squares method.

Enzyme activity values were fitted by the second order polynomial equation

$$
Y=\beta 0+\sum \beta i x i+\sum \beta i i x i^{2}+\sum \sum \beta i j x i x j
$$

Where, $\mathrm{Y}$ is the predicted response variable,

$\beta 0$ is the intercept,

$\beta i, \beta i i$ and $\beta i j$ are linear, quadratic and interaction coefficients respectively,

$x i$ and $x j$ are the coded forms of the independent variables.

\section{Interpretation and data analysis}

The results of the experimental design were analysed and interpreted using the MINITAB version 16 (PA, USA) statistical software. Prediction of optimum fermentation parameters and shape of the curves generated by the model was also done by the same software.

\section{Enzyme extraction}

The crude enzyme from each flask was extracted by adding $20 \mathrm{ml}$ of $0.05 \mathrm{M}$ glycine- $\mathrm{NaOH}$ buffer ( $\mathrm{pH} 9.0$ ) and then the entire content was filtered through a wet muslin cloth by squeezing. The extract thus obtained was centrifuged at $8,000 \times \mathrm{g}$ for $15 \mathrm{~min}$. The volume of supernatant was measured and it was used to determine enzyme activity and concentration of soluble proteins.

\section{Enzyme assay}

Endo- $\boldsymbol{\beta}-\mathbf{1 , 4 - g l u c a n a s e}$ assay: The enzyme extract was diluted with $0.05 \mathrm{M}$ glycine- $\mathrm{NaOH}$ buffer ( $\mathrm{pH} 9.0)(0.5 \mathrm{ml})$ mixed with $2 \% \mathrm{CMC}$ $(0.5 \mathrm{ml})$ and incubated in a water bath at $50^{\circ} \mathrm{C}$ for $30 \mathrm{~min}$. The reaction was terminated using DNS reagent followed by boiling and reducing sugar contents were estimated [40]. One unit of enzyme was defined as one micromole of glucose liberated per min under standard assay conditions.

\section{Endoglucanase gene cloning}

Genomic DNA isolation: Bacterial culture was inoculated into 100 $\mathrm{ml}$ of brain heart infusion broth and was allowed to grow overnight on a rotary shaker at $37^{\circ} \mathrm{C}$. Next day, cells were harvested by centrifugation at $6,000 \mathrm{~g}$ for $15 \mathrm{~min}$ at $4^{\circ} \mathrm{C}$ and resuspended in $5 \mathrm{ml}$ of SET buffer (SET buffer: $75 \mathrm{mM} \mathrm{NaCl}, 25 \mathrm{mM}$ EDTA, $20 \mathrm{mM}$ Tris, pH 8.0).

To carry out cell lysis, lysozyme was added to a concentration of 1 $\mathrm{mg} / \mathrm{ml}$ and incubated at $37^{\circ} \mathrm{C}$ for $0.5-1.0 \mathrm{~h} .1 / 10^{\text {th }}$ volume of $10 \%$ SDS along with $0.5 \mathrm{mg} / \mathrm{ml}$ of proteinase $\mathrm{K}$ were added and the mixture was incubated at $55^{\circ} \mathrm{C}$ with occasional inversions for $2 \mathrm{~h} .1 / 3^{\text {rd }}$ volume of 5 $\mathrm{M} \mathrm{NaCl}$ and equal volume of chloroform were added to the tubes and were mixed by inversion for $0.5 \mathrm{~h}$ at room temperature. After mixing the tubes were centrifuged at $6,000 \times \mathrm{g}$ for $15 \mathrm{~min}$. The aqueous phase was transferred to a new tube using a blunt ended tip. Finally DNA was precipitated by adding equal volume of isopropanol. Precipitated DNA was gently transferred into micro centrifuge tubes and centrifuged. The pellet obtained was washed with $70 \%$ ethanol at $10,000 \times \mathrm{g}$ for 10 min. Supernatant was discarded and ethanol was evaporated the pellet obtained was dissolved in appropriate volume of TE buffer [12].

\section{Primer design}

A single set of primer was designed manually, complimentary to the Bacillus licheniformis Cel12A gene sequence available in UNIPROTKB nucleotide database. This includes Forward primer 5'-GGATCCATGAAAAACAACCATTTGCTA-3') containing BamHI recognition site (underlined) and reverse primer (5'-CTCGAGTCAGCGGACCGTTACGTCCCA-3') with XhoI recognition site.

\section{Amplification of endoglucanase gene}

The gene for cellulase was amplified using primer pair generated on the basis of the sequence of cellulase gene of the same genus. Primers were obtained from Integrated DNA Technologies (http://eu.idtdna. com/). The Cel12A gene was amplified through Polymerase Chain Reaction (PCR) having total reaction volume of $20 \mu$, which contained $10 \mathrm{ng}$ of template genomic DNA, 10 pmol of each primer, $2.5 \mathrm{mmol}$ of each dNTP, $2 \mu \mathrm{l}$ of $10 \mathrm{X}$ Taq buffer, and $2 \mathrm{U}$ of Taq DNA polymerase. The PCR procedure comprised 30 cycles of $1 \mathrm{~min}$ at $94^{\circ} \mathrm{C}, 30 \mathrm{sec}$ at $58^{\circ} \mathrm{C}$, and $1 \mathrm{~min}$ at $72^{\circ} \mathrm{C}$. A final extension at $72^{\circ} \mathrm{C}$ for $5 \mathrm{~min}$ was performed after 30 cycles. The amplified product was checked on $1 \%$ agarose gel stained with ethidium bromide and observed on an UV transilluminator.

\section{Elution of amplified gene}

Elution of amplified gene product was carried out with the help of gel extraction kit (Merck, India). The procedures were followed according to the manufacturer's protocol provided along with the Gel extraction kit.

\section{Restriction digestion of Cel12A gene and pRSETA vector}

Digestion of the insert and the expression vector were carried out 
Citation: Dave BR, Parmar P, Sudhir A, Panchal K, Subramanian RB (2015) Optimization of Process Parameters for Cellulase Production by Bacillus licheniformis MTCC 429 using RSM and Molecular Characterization of Cellulase Gene. J Bioprocess Biotech 5: 212 doi: 10.4172/21559821.1000212

by taking $1 \mu \mathrm{g}$ of pRSETA vector and $300 \mathrm{ng}$ of insert. 5 units of both the enzymes were added to the mixture with, $2 \mu \mathrm{l}$ BSA (Bovine serum albumin) and $10 \mu \mathrm{l}$ buffer. Total volume of the mixture was made up to $100 \mu \mathrm{l}$ with nuclease free water and incubated at $37^{\circ} \mathrm{C}$ overnight, followed by incubation at $65^{\circ} \mathrm{C}$ for $10 \mathrm{~min}$ for the deactivation of the enzymes. Confirmation of the digestion process was carried out by separating the mixtures on $1 \%$ agarose gel. Again insert and vector were eluted and purified from agarose gel.

\section{Cloning}

The purified PCR fragment and pRSETA vector were dissolved in appropriate amount of TE buffer and the DNA concentration was determined by absorbance at $260 \mathrm{~nm}$. Into a $0.5 \mathrm{ml}$ micro centrifuge tube, a ligation reaction of $20 \mu \mathrm{l}$ was kept having 3:1 ratio of insert: vector along with $10 \times$ ligation buffer $2 \mu \mathrm{l}$ and T4 DNA ligase enzyme 1 $\mu \mathrm{l}$. The reaction was incubated at $16^{\circ} \mathrm{C}$ overnight.

\section{Transformation}

Preparation of competent cells of $\boldsymbol{E}$. coli DH5a: For preparation of competent cells, a well isolated, single colony of DH5a was picked from the Luria Bertani agar plate and inoculated into $5 \mathrm{ml}$ of LB broth and incubated at $37^{\circ} \mathrm{C}$ (in a shaker) overnight. $1 \mathrm{ml}$ of the overnight culture was further inoculated into $100 \mathrm{ml}$ of LB broth and the flask was incubated at $37^{\circ} \mathrm{C}$ in a shaker till the O.D $A 600$ reached 0.600 . The cultured flask was chilled on ice for 10-20 min and it was aseptically transferred into sterile centrifuge tubes and spun at $4,000 \times \mathrm{g}$ for $8 \mathrm{~min}$ at $4^{\circ} \mathrm{C}$. The supernatant was discarded and to the cell pellet, approximately $15 \mathrm{ml}$ of cold $0.1 \mathrm{M} \mathrm{CaCl}_{2}$ solution was added aseptically. The pellet was suspended using pre-chilled pipette tips by aspiration.

The tubes were transferred to ice for $30 \mathrm{~min}$ followed by centrifugation at $4,000 \times \mathrm{g}$ for $8 \mathrm{~min}$ at $4^{\circ} \mathrm{C}$. The aqueous phase was discarded and pellet was resuspended gently in $0.6 \mathrm{ml}$ of cold $0.1 \mathrm{M}$ $\mathrm{CaCl}_{2}$ solution. These competent cells of E. coli DH5a were used for transformation [41].

\section{Transformation of Cel12A gene in E. coli DH5a}

$14 \mu \mathrm{l}$ of ligated sample was mixed with $100 \mu \mathrm{l}$ of competent cells and the tube was kept on ice for $30 \mathrm{~min}$. Heat shock treatment was given to the sample tube for $2 \mathrm{~min}$ at $42^{\circ} \mathrm{C}$, followed by incubation on ice for 5 min. To the sample tube, $900 \mu \mathrm{LB}$ was added and incubated at $37^{\circ} \mathrm{C}$ for $1 \mathrm{~h}$. The sample was centrifuged at $6,000 \times \mathrm{g}$ for $5 \mathrm{~min}$, the supernatant was discarded (around $900 \mu \mathrm{l}$ ) and the pellet was resuspended in $100 \mu \mathrm{l}$ of Luria broth. Aliquots of the sample were spread on Luria agar plates containing $100 \mu \mathrm{g} / \mathrm{ml}$ of ampicillin. The transformants were selected by their ability to grow on ampicillin containing LB plates [41].

\section{Plasmid DNA isolation}

Plasmids were isolated using alkali lysis method. The transformants from the ampicillin plate were picked up and inoculated into $10 \mathrm{ml}$ of Luria broth and were incubated under shaking condition at $37^{\circ} \mathrm{C} .1 .5$ $\mathrm{ml}$ of cell suspension was transferred into the micro centrifuge tube and centrifuged at $10,000 \times \mathrm{g}$ for $1 \mathrm{~min}$ at $4^{\circ} \mathrm{C}$. Supernatant was completely removed and pellet was resuspended in $100 \mu \mathrm{l}$ of solution-I (glucose $0.9 \%, 0.025 \mathrm{M}$ Tris, $0.01 \mathrm{M}$ EDTA). Then $200 \mu \mathrm{l}$ of solution-II (0.2 N $\mathrm{NaOH}, 1 \%$ SDS) was added and tubes were invert mixed slowly once and then $150 \mu \mathrm{l}$ of solution-III ( $3 \mathrm{M}$ potassium acetate, $11.5 \%$ glacial acetic acid) was added and tubes were invert mixed once more. Cell debris and proteins were removed by centrifugation at $19.000 \mathrm{~g}$ at $4^{\circ} \mathrm{C}$. $0.8^{\text {th }}$ volume of isopropanol was added to the solution and tubes were incubated at room temperature for $2 \mathrm{~h}$. The tubes were centrifuged at
$20,000 \times \mathrm{g}$ for $25 \mathrm{~min}$ at $4^{\circ} \mathrm{C}$, pellet washed with chilled $70 \%$ ethanol and air dried. Finally plasmids were resuspended in $35 \mu \mathrm{l}$ of MQ water. $5 \mu \mathrm{l}$ of plasmid were checked on $1 \%$ agarose gel.

\section{Confirmation of clones through gene specific PCR}

Confirmation of plasmids containing Cel12A gene was carried out with the gene specific PCR. The gene specific primers were used to amplify gene of interest using plasmids isolated from E. coli DH5a cells as templates. PCR conditions were similar as described for amplification of Cel12A from genomic DNA of Bacillus licheniformis. The amplified product was checked on $1 \%$ agarose gel stained with ethidium bromide and observed on an UV transilluminator.

\section{Sequencing}

The confirmed recombinant plasmids were processed for sequencing. The plasmid was sequenced by automated DNA analyzer 3730 using ABI PRISM ${ }^{\circ}$ BigDye ${ }^{\mathrm{TM}}$ Terminator Cycle Sequencing 3.1 (Applied Biosystems, Foster City, CA). The sequencing was carried out with the help of universal primers of $\mathrm{T} 7$ promoter.

\section{Results and Discussion}

\section{Optimization of fermentation parameters by response surface methodology using box behnken design}

Optimization of any process or process conditions can be effectively carried out with the involvement of Response Surface Methodology. Response Surface Methodology has been effectively employed for optimization of fermentation parameters for solid state fermentation by many research groups. This method has been successfully applied in the optimization of fermentation medium components, conditions for enzymatic hydrolysis and fermentation processes [37,42-45]. It allows the calculation of maximum enzyme production based on few sets of experiments in which all the factors are varied within selected range and also to study interactive effects of various process parameters [46]. The results of 15 run BBD in three variables, initial $\mathrm{pH}$ of the medium, substrate to moisture ratio and incubation time for the optimization of cellulase production are shown in Table 3.

ANOVA (analysis of variance) was employed for the determination of significant effects of variables for cellulase production. Cellulase

\begin{tabular}{|c|c|c|c|c|}
\hline \multirow{2}{*}{$\mathbf{S . N o}$} & \multicolumn{3}{|c|}{ Process variables } & \\
\cline { 2 - 5 } & $\begin{array}{c}\text { Initial pH } \\
\mathrm{X}_{1}\end{array}$ & $\begin{array}{c}\text { Moisture ratio } \\
\mathrm{X}_{2}\end{array}$ & $\begin{array}{c}\text { Incubation time } \\
\mathrm{X}_{3}\end{array}$ & $\begin{array}{c}\text { Endo- } \mathbf{\beta}-\mathbf{1 , 4}-\mathbf{g l u c a n a s e} \\
\text { activity (U) }\end{array}$ \\
\hline $\mathbf{1}$ & 1 & 1 & 0 & 1.267 \\
\hline $\mathbf{2}$ & -1 & -1 & 0 & 0.437 \\
\hline $\mathbf{3}$ & 0 & 0 & 0 & 1.496 \\
\hline $\mathbf{4}$ & 1 & 0 & 1 & 2.111 \\
\hline $\mathbf{5}$ & 0 & -1 & -1 & 0.837 \\
\hline $\mathbf{6}$ & -1 & 0 & -1 & 0.378 \\
\hline $\mathbf{7}$ & 0 & 0 & 0 & 1.326 \\
\hline $\mathbf{8}$ & 0 & 1 & 1 & 1.948 \\
\hline $\mathbf{9}$ & -1 & 0 & 1 & 1.844 \\
\hline $\mathbf{1 0}$ & -1 & 1 & 0 & 0.156 \\
\hline $\mathbf{1 1}$ & 0 & 1 & -1 & 0.459 \\
\hline $\mathbf{1 2}$ & 0 & 0 & 0 & 1.126 \\
\hline $\mathbf{1 3}$ & 0 & -1 & 1 & 1.882 \\
\hline $\mathbf{1 4}$ & 1 & 0 & -1 & 0.556 \\
\hline $\mathbf{1 5}$ & 1 & -1 & 0 & 0.378 \\
\hline
\end{tabular}

Table 3: Full factorial Box-Behnken Design for production of cellulase from Bacillus licheniformis and its activity. 
Citation: Dave BR, Parmar P, Sudhir A, Panchal K, Subramanian RB (2015) Optimization of Process Parameters for Cellulase Production by Bacillus licheniformis MTCC 429 using RSM and Molecular Characterization of Cellulase Gene. J Bioprocess Biotech 5: 212 doi: 10.4172/21559821.1000212

production varied markedly with the conditions tested in the range of 0.156-2.11 U/g. It was observed from various experimental runs that cellulase production was quite high with higher $\mathrm{pH}$ and incubation time. Moreover, it was observed that the moisture ratio at 1:1 gave maximum cellulase activity which decreased with increased moisture ratio. The lowest level of endo- $\beta$-1,4-glucanase was observed with Run no 10, having low point value of initial $\mathrm{pH}, \mathrm{pH} 7.0$ (coded value -1 ), highest point value of moisture ratio, 1:1.5 (coded value +1 ) and medium value of incubation time $48 \mathrm{~h}$ (coded value 0 ). Having all the conditions not in favor for production of enzyme, strain Bacillus licheniformis showed very less production of endo- $\beta$-1,4-glucanase $(0.156 \mathrm{U} / \mathrm{g})$. With increasing initial $\mathrm{pH}$ of the medium (coded value 1$)$, increase in enzyme production was observed. Maximum endo- $\beta-1,4-$ glucanase activity was supported at pH 9.0 (coded value 1) (Run no. 4). Along with increased $\mathrm{pH}$, incubation time also supported production of enzyme at its medium value (coded value 1). The experimental results suggest that the variables selected for the fermentation process had strong effect on cellulase production.

The coefficient for the linear effect of incubation time was highly significant while initial $\mathrm{pH}$ was statistically significant with $10 \%$ error. However, in square terms all three variables were found to exert significant influence on endo- $\beta$-1,4-glucanase production $(\mathrm{p}<0.05)$. In addition, the interactive effect between initial $\mathrm{pH}$ and moisture ratio was significant at $(\mathrm{p}<0.05)$ and had a positive influence on endo- $\beta-1,4-$ glucanase production (Table 4 ).

On the basis of these experimental values, statistical testing was carried out using the Fisher's ' $F$ '-test and students 'T'-test. Analysis of variance for cellulase production shows that fitted second order response surface model is highly significant with $\mathrm{F}$ test $=13.41(\mathrm{P}=$ $0.005)$ as shown in Table 5.

The fitted second order response surface model as specified by

\begin{tabular}{|c|c|c|}
\hline Term & \multicolumn{2}{|c|}{ Endo- $\boldsymbol{\beta}-\mathbf{1 , 4 - g l u c a n a s e}$} \\
\hline & Coefficient & $\boldsymbol{P}$ \\
\hline Constant & 1.31603 & 0.000 \\
\hline $\mathbf{X}_{1}$ & 0.18705 & 0.064 \\
\hline $\mathbf{X}_{2}$ & 0.03705 & 0.659 \\
\hline $\mathbf{X}_{3} \mathbf{X}_{1}$ & 0.69443 & 0.000 \\
\hline $\mathbf{X}_{\mathbf{2}} \mathbf{X}_{2}$ & -0.40800 & 0.017 \\
\hline $\mathbf{X}_{3} \mathbf{X}_{3}$ & -0.34875 & 0.030 \\
\hline $\mathbf{X}_{1} \mathbf{X}_{2}$ & 0.31420 & 0.043 \\
\hline $\mathbf{X}_{1} \mathbf{X}_{3}$ & 0.29258 & 0.047 \\
\hline $\mathbf{X}_{2} \mathbf{X}_{3}$ & 0.02223 & 0.850 \\
\hline
\end{tabular}

Table 4: Estimated regression coefficient and corresponding $p$ value for endo- $\beta$ 1,4-glucanase activity.

\begin{tabular}{|l|c|c|c|l|l|}
\hline Source & $\begin{array}{c}\text { Degree of } \\
\text { freedom (DF) }\end{array}$ & $\begin{array}{c}\text { Sum of } \\
\text { squares (SS) }\end{array}$ & $\begin{array}{c}\text { Mean of } \\
\text { squares (MS) }\end{array}$ & F & P \\
\hline Regression & 9 & 6.03745 & 0.67083 & 13.41 & 0.005 \\
\hline Linear & 3 & 4.14869 & 1.38290 & 27.64 & 0.002 \\
\hline Square & 3 & 1.49503 & 0.49834 & 9.96 & 0.015 \\
\hline Interaction & 3 & 0.39373 & 0.13124 & 2.62 & 0.163 \\
\hline Residual Error & 5 & 0.25020 & 0.05004 & & \\
\hline Lack-of-Fit & 3 & 0.18146 & 0.06049 & 1.76 & 0.382 \\
\hline Pure Error & 2 & 0.06874 & 0.03437 & & \\
\hline Total & 14 & 6.28766 & & & \\
\hline
\end{tabular}

Table 5: ANOVA of endo- $\beta-1,4-$ glucanase activity: Effect of initial $\mathrm{pH}$, moisture ratio, and incubation time.

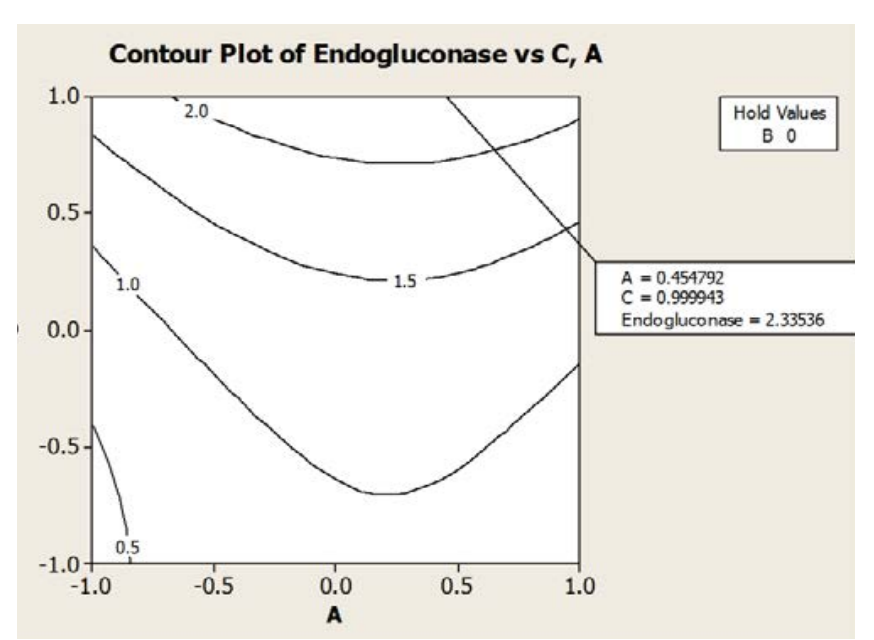

Figure 1: Contour plot of interaction effect of initial $\mathrm{pH}$ and incubation time, on endo- $\beta-1,4-$ glucanase activity while keeping moisture ratio unchanged.

Equation (5.3) for cellulase activity in coded process variables is:

$\eta($ Endo- $\beta$ - 1,4 -glucosidase $)=(1.3160)+\left(0.1870\left(\mathrm{X}_{1}\right)+\left(0.0370\left(\mathrm{X}_{2}\right)\right.\right.$ $+\left(0.6944\left(\mathrm{X}_{3}\right)+\left(-0.4080\left(\mathrm{X}_{1}{ }^{2}\right)+\left(-0.3487\left(\mathrm{X}_{2}{ }^{2}\right)+\left(0.3142\left(\mathrm{X}_{3}{ }^{2}\right)+\right.\right.\right.\right.$ $\left(0.2925\left(\mathrm{X}_{1} \mathrm{X}_{2}\right)+\left(0.0223\left(\mathrm{X}_{1} \mathrm{X}_{3}\right)+\left(0.1107\left(\mathrm{X}_{2} \mathrm{X}_{3}\right)\right.\right.\right.$

The coefficient of determination $\mathrm{R}^{2}$ for the above predicted Equation (5.3) was $96 \%$. Therefore, this equation can be used for predicting the response at any combination of three predicted variables in and around their experimental range.

The enzyme activities ( $\eta$ ) at specified combination of the three variables can be predicted by substituting the corresponding coded values in the equation.

The contour plot based on Equation 5.3 was prepared using MINITAB 16 software. The contour plot (Figure 1) shows the behavioral change with respect to simultaneous change in two variables. Proper choice of fermentation parameters is desirable for maximum enzyme production and contour plots based on well fitted model provides these choices [46]. Contour plot was prepared for three pairs of variables which were having significant interaction effects in maximizing cellulase production at specific hold values. The behavior of cellulase activity $(\mathrm{U} / \mathrm{g})$ with respect to change in initial $\mathrm{pH}(\mathrm{A})$ and incubation time $(\mathrm{C})$ and moisture ratio at hold values is shown in Figure 1. From the contour plot, it is evident that, the increase in initial $\mathrm{pH}$ and incubation time had positive effect in yielding higher cellulase activity.

All the parameters affected enzyme production in terms of squares. One of the parameters tested is the initial $\mathrm{pH}$ of the medium, which is an important parameter considered in any production optimization process because of the fact that any enzyme produced by microorganisms can be stable at a particular $\mathrm{pH}$ value. Bacillus is generally able to grow over a wide range of $\mathrm{pH}$ values. The enzymes produced by this genus are also stable over a wide range of $\mathrm{pH}$. The $\mathrm{pH}$ values below and above the optimum value required for growth as well as enzyme production lead to slower growth rate along with low levels of enzyme secretion. Moreover, the extracellular enzyme produced will also have conditions which lead to the inactivation of the enzyme. Bacillus sp. JB-99 was also able to grow over a wide range of $\mathrm{pH}(6-12)$ and it required an alkaline $\mathrm{pH}(8-10)$ for growth and enzyme secretion [47]. Optimization of fermentation conditions like initial $\mathrm{pH}$ value of the medium is hence an important parameter. 
Citation: Dave BR, Parmar P, Sudhir A, Panchal K, Subramanian RB (2015) Optimization of Process Parameters for Cellulase Production by Bacillus licheniformis MTCC 429 using RSM and Molecular Characterization of Cellulase Gene. J Bioprocess Biotech 5: 212 doi: 10.4172/21559821.1000212

The change of moisture content and incubation time was significant. Studies related to interaction of moisture ratio and incubation time are not reported so far, but at the same time selection of appropriate time for enzyme extraction was found to be an important parameter in various studies. The time of fermentation played an important role in the study. Maximum enzyme production was obtained after $72 \mathrm{~h}$ of fermentation. Bacillus sp. has been reported to produce maximum enzyme after $72 \mathrm{~h}$ fermentation using various substrates by many researchers $[11,13,25,48-50]$. Results obtained in the present study are in complete agreement with the reports on cellulase production by Bacillus spp.

The moisture content of the substrate is one of the critical factors influencing the outcome of SSF, and is governed by the water-holdingcapacity of the substrate, the type of end-product and the requirement of the microorganism. At low moisture content, metabolic and enzymatic activities are reduced. Higher moisture levels decrease the porosity of substrate leading to gummy structure, which limits oxygen transfer and reduces growth [25,51-53].

Reductions in enzyme yield with high moisture content [54] and with low moisture content [55] have also been reported.

Application of RSM with BBD predicted that maximum cellulase production must occur at decoded values of process parameters as initial $\mathrm{pH}\left(\mathrm{X}_{1}=+0.454\right)$, moisture ratio $\left(\mathrm{X}_{2}=0\right)$ and incubation time $\left(\mathrm{X}_{3}=+0.99\right)$. The model predicted cellulase production $2.33536 \mathrm{U} / \mathrm{g}$ at optimum parameters.

The optimization of cellulase production under solid state fermentation showed an interesting study on utilization of Jatropha deoiled seed cake as a substrate using Bacillus licheniformis as the producing microorganism. Though it gives insights into use of the substrate and abilities of microorganisms to utilize such a toxic substrate without any pretreatment, lower yield of the endo- $\beta$ - 1,4 -glucanase suggests the use of some other ways to increase the production of the enzyme. The potential of the alkaline cellulases secreted by Bacillus

spp. are very well known along with many reports by various research groups. Endoglucanase from Bacillus licheniformis was produced at $\mathrm{pH}$ 9.0. Hence, studying this enzyme further will be an interesting research topic. More over literature survey and sequence data present in NCBI showed a few studies on gene amplification, cloning and expression of endoglucanase from Bacillus licheniformis. It was also found that predicted protein sequence of endoglucanase from Bacillus licheniformis do not contain cellulose binding module. The lower activities observed in the present study might also be due to lack of CBM in the cellulase.

Considering all the above facts, it was decided to study this enzyme with available molecular biology techniques for gene amplification, cloning and over expression followed by purification of recombinant protein.

\section{Molecular characterization}

Isolation of genomic DNA: Figure 2 depicts good quality genomic DNA from Bacillus licheniformis. DNA obtained had a purity ratio of 1.6. (A260 nm: $A 280 \mathrm{~nm}$ ). Genomic DNA thus obtained was used for the endoglucanase gene amplification by PCR using universal primers.

Amplification of cell2A: The presence of a gene for cellulase in Bacillus spp. has been reported by many researchers [56-60]. The endoglucanases found among various strains of Bacillus spp. are of different gene sizes with different properties. Alkaline cellulases from Bacillus licheniformis have been reported by Liu et al. [31]. Characterization of Cel12A from the library generated by Liu et al. [31] suggests a predicted open reading frame of 261 amino acids. The genes for endoglucanase enzyme reported by researchers have different sizes according to the class of the enzyme like Cel9A, Cel12A, Cel5A. The gene encoding Cel12A was found in Bacillus licheniformis having alkaline $\mathrm{pH}$ optima and good thermal stabilities. Hence the gene sequence available in NCBI GenBank database was searched for Cel12A of Bacillus licheniformis and primers were designed according to the full length sequence of the enzyme. This set of primers gave specific amplification, producing a sharp band on an agarose gel. The expected product size for this primer pair was $786 \mathrm{bp}$ and nearly 800 base pairs of specific amplification obtained, as confirmed by agarose gel electrophoresis. The PCR product thus obtained was eluted from the gel using a gel extraction kit (Merck, India). This eluted product was further used for the cloning of the insert into vector (Figure 3).

Restriction digestion: Agarose gel electrophoresis after the restriction digestion of insert as well as vector pRSETA showed sharp bands at $\sim 800 \mathrm{bp}$ and $2.9 \mathrm{~kb}$ respectively. The figure shows bands of insert (Cel12A gene) and plasmid pRSETA on agarose gel along with

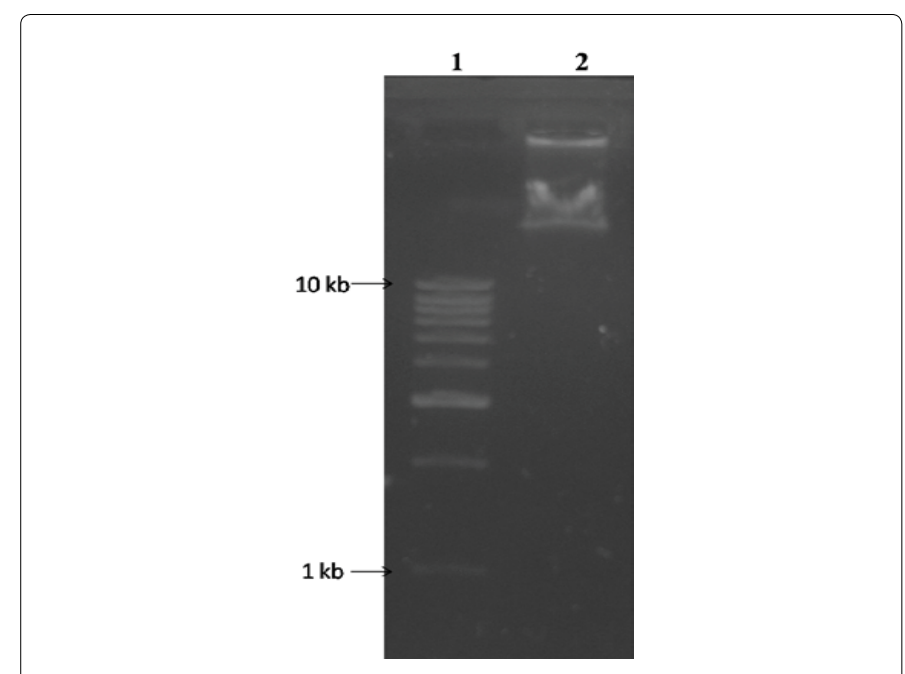

Figure 2: Isolation of genomic DNA from Bacillus licheniformis. Lane 1: $1 \mathrm{~kb}$ DNA ladder, Lane 2: genomic DNA.

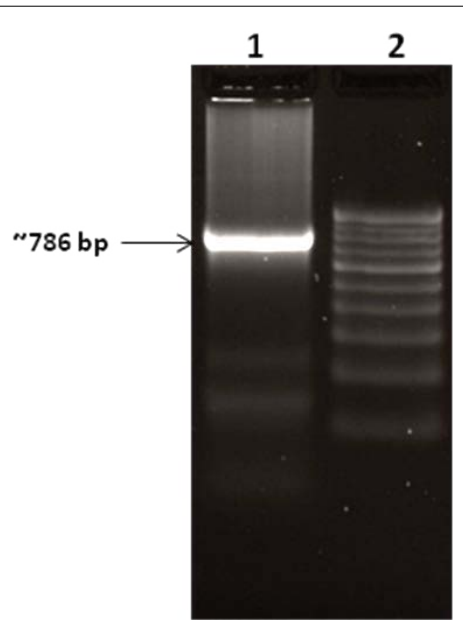

Figure 3: Amplification of Cel12A gene from genomic DNA of Bacillus licheniformis Lane 1: amplification of Cel12A, Lane 2: 100 bp DNA ladder. 
Citation: Dave BR, Parmar P, Sudhir A, Panchal K, Subramanian RB (2015) Optimization of Process Parameters for Cellulase Production by Bacillus licheniformis MTCC 429 using RSM and Molecular Characterization of Cellulase Gene. J Bioprocess Biotech 5: 212 doi: 10.4172/21559821.1000212

Page 7 of 9

the appropriate markers (Figure 4). Results obtained in figure shows linearization of plasmids; hence it confirms that plasmid as well as insert was successfully digested by BamHI and XhoI restriction enzymes.

Cloning of cellulase gene: Purified insert and vector (pRSETA) with sticky ends were ligated using T4 DNA ligase (NEB). Ligated

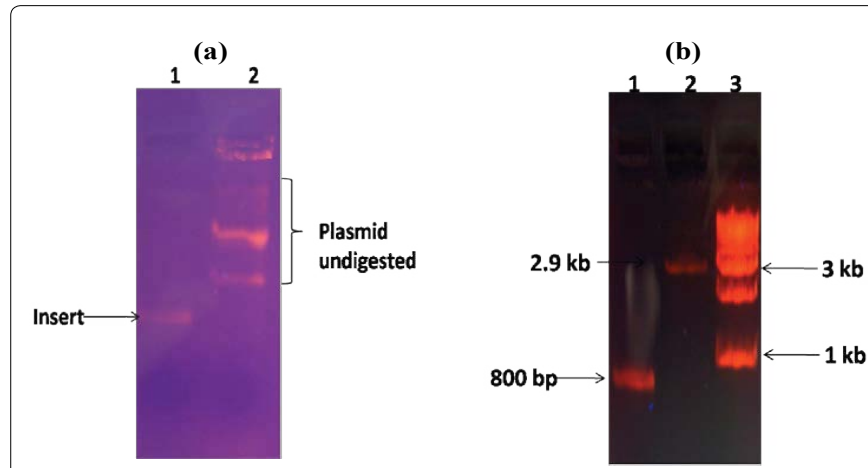

Figure 4: Restriction digestion of Cel12A and pRSETA (a) Lane 1: undigested insert, Lane 2: undigested vector pRSETA (b) Lane 1: digested insert, Lane 2 : digested vector, Lane 3: $1 \mathrm{~kb}$ DNA ladder. mixture was then transformed into competent cells of $E$. coli $\mathrm{DH} 5 \alpha$ by heat shock method. The transformed cells were then plated on Luria Agar plate containing $50 \mu \mathrm{g} / \mathrm{ml}$ ampicillin. The transformants were further used to isolate plasmid DNA by alkali lysis method and selected with application of gene specific primers (Cel12AFP and Cel12ARP) for the amplification of Cel12A gene and by restriction digestion and release of insert [61].

Sequencing and BLAST analysis: The plasmids showing amplification of Cel12A gene with gene specific PCR were sent for sequencing. A nucleotide sequence of the $1000 \mathrm{bp}$ was obtained. Out of $1000 \mathrm{bp}$ sequence a $786 \mathrm{bp}$ open reading frame was found to be coding for Cel12A. The open reading frame encoding Cel12A was confirmed with BLAST analysis. The BLAST analysis showed its $100 \%$ identity towards glycosyl hydrolase family 12 enzymes of Bacillus licheniformis. Sequence similarity data is as shown in the Table 6 . The sequence of the Cel12A gene from Bacillus licheniformis was submitted to NCBI under the Accession number: JQ846014.

BLAST analysis of deduced amino acid sequence: The deduced amino acid sequence encoding Cel12A was generated from the sequence data available in the form of nucleotides. The amino acid sequence was aligned with the amino acid sequences of other organisms using UniprotKB programme. The results obtained are as below.

1
1
1
1
1
1
1

58
58
58
61
61
60
61

118
118
118
121
121
120
121

--MKNNH-LLKSILLWGAVCIIVLAGPLSAFAASSSNPSDKLYFKNKKYYIFNNVWGADO

--MKNNH-LLKSILLWGAVCIIVLAGGLSAFAASSSNPSDKLYFKNKKYYI FNNVWGADO --MKNNH-LLKSILLWGAVCIIVLAGPLSAFAASSSNPSDKL YFKNKKYYI FNNVWGADQ MOTVNTOPHRIFCVLLPAVFSSLLLSSLTASAASSSNDADKFYFENNKYYYFNNVWGKDE MLITNTOSORTERTILI PVILISALI SPITVSAASSSKDADKL YFENNKYYYVFNNVWGKDE MKRVQRISTK-IGALSAVLML_ASVL_AVSAATAASTSADGGKVYFDNNKOYLFNNAWGKSS MLTVNKNPORIFRTLFPVLFSALLLSPLTVSAVSSSKDADKL YFENNKYYVFNNVWGKDE

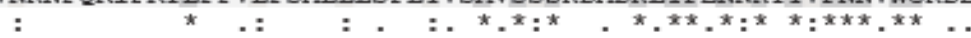

VSGWWQTIYHNSDSDMGWVWNWPSNTSTVKAYPSIVSGWHWTEGYTAGSGFPTRLSDQKN VSGWWOTIYHNSDSDMGWVWNWPSNTSTVKAYYPSIVSGWHWTEGYTAGSGFPTRLSDQKN VSGWWQTIYHNSDSDMGWVWNWPSNTSTVKAYPSIVSGWHWTEGYTAGSGFPTRLSDQKN VKGWROTVFYNSPTSMGWNWHIVPSSSHSVKAYPSLVSGWHWTAGYTENSGLPIKL SSNKS VSGWSOSVYYNNASDLGWVWNWPTTSGGVKGYPSIVSGWHWTDGYTAGSGFPTRIWDNKN VKGWQQTVFYNSPTSMGWNWHWPSSSSSVKGYPSLVSGWHWTAGYTENSGLPIKLSSNKS

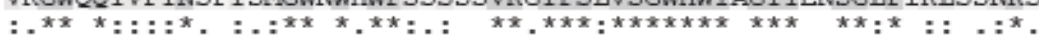

INTKVSYSIS--ANGTYNAAYDIWLHNTNKASWDSAPTDETMTWLNNTNAGPAGSYVETV INTKVSYSIS--ANGTYNAAYDIWLHNTNKASWDSAPTDEIMIWLNNTNAGPAGSYVETV INTKVSYSIS--ANGTYNAAYDIWLHNTNKASWDSAPTDEIMIWLNNTNAGPAGSYVETV ITSNVTYSIQ--AMGTYNA_AYDIWFHTTDKANWDSPPTDELMIWLNDTNAGPAGDYIETV ITSNVTYSIK--STGTYNATYDIWFHTTDKANWDSTPTDELMIWLNNTNAGPAGDYIETV INTSVTYNFA.SNTSGVYNMTYDLWLHDTNNAKYNSRPTDEIMVWLNNTNAGALGTYIETV ITSNVTYSIK--STGTYNAAYDIWFHTTDKANWDSTPTDELMIWLNNTNAGPAGDYIETV

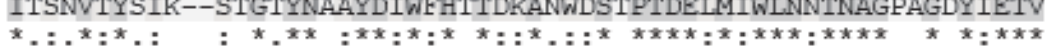

176 SIGGHSWKVYKGYIDAGGGKGWNVFSFIRTANTQSANLNIRDFTNYL.ADSKQWLSKTKYV 176 SIGGHSWKVYKGYIDAGGGKGINVF SFIRTANTOSANT NTRDFTTYIADSKOVI SKTKYV

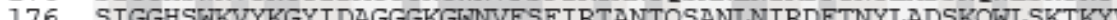

179 FIGGSSWNVFKGWINADNGGGWNVFSFVHTSSTNSASLNIRHFTDYLVETKOWMSDEKYI 179 FIGGSSWNVFKGWINADNGGGWNVFSFVHTSSTNSASLNIRHFTDYLVETKQWMSDEKYI 180 SIGGSSWNVYKGYVDDGTGGGWNVFSYLRTANTNSIDLNLKNFADHAVYTKKWIANSKYI

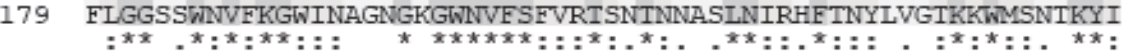

57 BI

57 BLATCC

57 BS

60 PW

60 PC

59 PM

60 EC

117 BL

117 BLATCC

117 BS

120 PW

120 PC

$119 \mathrm{PM}$

120 EC

175 BL

175 BLATCC

175 BS

178 PW

178 PC

$179 \mathrm{PM}$

178 EC

\section{BL}

235 BLATCC

235 BS

238 PW

238 PC

$239 \mathrm{PM}$

238 EC

\begin{tabular}{|c|c|c|c|}
\hline 236 & SSVEFGTEVFGGTGQINISNWDVTVR & 261 & BL \\
\hline & SSVEFGTEVFGGTGQINISNWDVTVR & 261 & BL.A \\
\hline 36 & SSVEFGTEVFGGTGQINISNWDVIVR & 261 & BS \\
\hline 239 & SSVEFGTEIFGGDGQIDITEWRVDVK & 264 & PW \\
\hline & SSVQFGTEIFGGDGQIDITKWSVDVK & & PC \\
\hline & SSVEFGTEVSSGSGQVNLSRWSLSVQ & 265 & PM \\
\hline 39 & SSVQFGTEIFGGDGQIDITKWNVDVK & 264 & EC \\
\hline
\end{tabular}

Figure 5: Jalview representation of multiple sequence alignment of $B$. licheniformis (Cel12A) with other glycosyl hydrolase family $\beta$-glucanases BL: Bacillus licheniformis (Cel12A) deduced amino acid sequence. BLATCC: Bacillus licheniformis DSM13 (Cel12A). BS: Bacillus sp; PW: Pectobacterium wasabiae; PC: Pectobacterium carotovorum subsp. Carotovorum; PM: Paenibacillus mucilaginosus; EC: Erwinia carotovora subsp. atroseptica (strain SCRI 1043 / ATCC BAA-672). 
Citation: Dave BR, Parmar P, Sudhir A, Panchal K, Subramanian RB (2015) Optimization of Process Parameters for Cellulase Production by Bacillus licheniformis MTCC 429 using RSM and Molecular Characterization of Cellulase Gene. J Bioprocess Biotech 5: 212 doi: 10.4172/21559821.1000212

Page 8 of 9

\begin{tabular}{|c|c|c|c|c|c|}
\hline Entry & Protein names & Organism & Length & Identity & Score \\
\hline Q65FM6 & Glycoside Hydrolase 12 (Uncharacterized protein) & Bacillus licheniformis (strain DSM 13) & 261 & $100 \%$ & 1435 \\
\hline Q7X4S4 & Endo-beta-1,4-glucanase (EC 3.2.1.4) & Bacillus licheniformis & 261 & $100 \%$ & 1435 \\
\hline E5W7D6 & Endo-beta-1,4-glucanase & Bacillus sp. BT1B_CT2 & 261 & $100 \%$ & 1435 \\
\hline I0UJW3 & Glycoside hydrolase family protein & $\begin{array}{l}\text { Bacillus licheniformis } \\
\text { WX-02 }\end{array}$ & 261 & $99 \%$ & 1430 \\
\hline H1AD15 & Endoglucanase & Bacillus licheniformis & 261 & $94 \%$ & 1382 \\
\hline C6DDT4 & Cellulase (EC 3.2.1.4) & Pectobacterium carotovorum subsp. carotovorum & 264 & $66 \%$ & 970 \\
\hline
\end{tabular}

Table 6: Sequence similarity of Cel12A with the sequences available in the database.

The Jalview representation of multiple sequence alignment shows similarity of sequences of various organisms' glycosyl hydrolase 12 with the deduced amino acid sequence of Cel12A (Figure 5). The similarity shown by the amino acid sequence confirms the existence of alkaline cellulase in Bacillus licheniformis. Moreover, it also states that the cloned gene sequence will encode an endoglucanase having properties like alkaline cellulases from Bacillus sp. Further expression of the cloned gene will provide insights about function of the expressed protein and its biochemical properties.

\section{References}

1. Ludwig W, Schleifer KH, Whitman WB (2009) Revised road map to the phylum Firmicutes. Bergey's Manual of Systematic Bacteriology, The Firmicutes. New York, NY: Springer-Verlag, USA, 3: 1-17.

2. Cohn O (1872) Untersuchungen über Bakterien. Beitrage zur Biologie der Pflanzen Heft.

3. Yakoubou S, Xu D, Côté JC (2010) Phylogeny of the Order Bacillales inferred from 3' 16S rDNA and 5' 16S- 23S ITS nucleotide sequences. Nat Sci 2: 990997.

4. Alcaraz LD, Moreno-Hagelsieb G, Eguiarte LE, Souza V, Herrera-Estrella L, et al. (2010) Understanding the evolutionary relationships and major traits of Bacillus through comparative genomics. BMC Genomics 11: 332.

5. Schallmey M, Singh A, Ward OP (2004) Developments in the use of Bacillus species for industrial production. Can J Microbiol 50: 1-17.

6. Hara T, Ueda S (1982) Regulation of polyglutamate in Bacillus subtilis (natto) transformation of high PGA productivity. Agric Biol Chem 46: 2275-2281.

7. Outtrup H, Jorgensen ST (2002) The importance of Bacillus species in the production of industrial enzymes. Applications and Systematics of Bacillus and Relatives. Berkley R, Heyndrickx M, Logan N, De Vos P, Blackwell Science Inc., Malden, Mass. pp. 206-218

8. Rao MB, Tanksale AM, Ghatge MS, Deshpande VV (1998) Molecular and biotechnological aspects of microbial proteases. Microbiol Mol Biol Rev 62: 597-635

9. Deka D, Bhargavi P, Sharma A, Goyal D, Jawed M, et al. (2011) Enhancement of Cellulase Activity from a New Strain of Bacillus subtilis by Medium Optimization and Analysis with Various Cellulosic Substrates. Enzyme Res 2011: 151656.

10. Anto H, Trivedi U, Patel K (2006) Alpha amylase production by Bacillus cereus MTCC1305 using solid-state fermentation. Food Technol Biotechnol 44: 241 245.

11. Trivedi N, Gupta V, Kumar M, Kumari P, Reddy CR, et al. (2011) Solvent tolerant marine bacterium Bacillus aquimaris secreting organic solvent stable alkaline cellulase. Chemosphere 83: 706-712.

12. Chudasama CJ, Jani SA, Jajda HM, Patel HN (2010) Optimization and production of alkaline protease from Bacillus thuringiensis cc7. J Cell Tiss Res 10: 2257-2262.

13. Krishna C (1999) Production of bacterial cellulase by solid state bioprocessing of banana wastes. Bioresour Technol 69: 231-239.

14. Krishna C, Chandrasekaran M (1996) Banana waste as substrate for $\alpha$-amylase production by Bacillus subtilis (CBTK 106) under solid-state fermentation. App Microbiol Biotechnol 46: 106-111.

15. Yin LJ, Lin HH, Xiao ZR (2010) Purification and characterization of a cellulase from Bacillus subtilis YJ1. J Marine Sci Technol 18: 466-471.
16. Ferreira S, Duarte AP, Ribeiro MHL, Queiroz JA, Domingues FC (2009) Response surface optimization of enzymatic hydrolysis of Cistus ladanifer and Cytisus striatus for bioethanol production. Biochem Eng J 45:192-200.

17. Balusus R, Paduru RR, Kuravi SK, Seenaya G, Reddy G (2005) Optimization of critical medium components using response surface methodology for ethanol production from cellulosic biomass by Clostridium thermocellum SS19. Process Biochem 40: 3025-3030

18. Wang Q, Ma H, Xu W, Gong L, Zhang W, et al. (2008) Ethanol production from kitchen garbage using response surface methodology. Biochem Eng $J$ 39: $604-610$

19. Das Neves MA, Kimura T, Shimizu N, Shiiba K (2006) Production of alcohol by simultaneous saccharification and fermentation of low-grade wheat flour. Braz Arch Biol Technol 49: 481-490.

20. Mojovic L, Nikolic S, Rakin M, Vukasinovic M (2006) Production of bioethanol from corn meal hydrolysates. Fuel 85: 1750-1755.

21. Bayer EA, Lamed R, Himmel ME (2007) The potential of cellulases and cellulosomes for cellulosic waste management. Curr Opin Biotechnol 18: 237 245

22. Gomez LD, Steele-King CG, McQueen-Mason SJ (2008) Sustainable liquid biofuels from biomass: the writing's on the walls. New Phytol 178: 473-485.

23. Himmel ME, Ding SY, Johnson DK, Adney WS, Nimlos MR, et al. (2007) Biomass recalcitrance: engineering plants and enzymes for biofuels production. Science 315: 804-807.

24. Araujo A, Ward OP (1990) Hemicellulases of Bacillus species: preliminary comparative studies on production and properties of mannanases and galactanases. J Appl Bacteriol 68: 253-261.

25. Archana A, Satyanarayana T (1997) Xylanase production by thermophilic Bacillus licheniformis A99 in solid state fermentation. Enz Microb Technol 21 12-17.

26. Berensmeier S, Singh SA, Meens J, Buchholz K (2004) Cloning of the pelA gene from Bacillus licheniformis 14A and biochemical characterization of recombinant, thermostable, high-alkaline pectate lyase. Appl Microbiol Biotechnol 64: 560-567.

27. Bischoff KM, Liu S, Hughes SR (2007) Cloning and characterization of a recombinant family 5 endoglucanase from Bacillus licheniformis strain B-41361. Process Biochem 42: 1150-1154.

28. Damiano VB, Ward R, Gomes E, Alves-Prado HF, Da Silva R (2006) Purification and characterization of two xylanases from alkalophilic and thermophilic Bacillus licheniformis 77-2. Appl Biochem Biotechnol 129-132: 289-302.

29. Feng YY, He ZM, Song LF, Ong SL, Hu JY, et al. (2003) Kinetics of betamannanase fermentation by Bacillus licheniformis. Biotechnol Lett 25: 11431146 .

30. Helianti I, Nurhayati N, Wahyuntari B (2008) Cloning, sequencing, and expression of a $\beta-1,4$-endoxylanase gene from Indonesian Bacillus licheniformis strain I5 in Escherichia coli. World J Microbiol Biotechnol 24: 1273-1279.

31. Liu Y, Zhang J, Liu Q, Zhang C, Ma Q (2004) Molecular cloning of novel cellulase genes cel9A and cel12A from Bacillus licheniformis GXN151 and synergism of their encoded polypeptides. Curr Microbiol 49: 234-238.

32. Liu MQ Liu GF (2008) Expression of recombinant Bacillus licheniformis xylanase A in Pichia pastoris and xylooligosaccharides released from xylans by it. Protein Expr Purif 57: 101-107.

33. Singh SA, Plattner H, Diekmann H (1999) Exopolygalacturonate lyase from a thermophilic Bacillus sp. Enzyme Microb Technol 25: 420-425. 
Citation: Dave BR, Parmar P, Sudhir A, Panchal K, Subramanian RB (2015) Optimization of Process Parameters for Cellulase Production by Bacillus licheniformis MTCC 429 using RSM and Molecular Characterization of Cellulase Gene. J Bioprocess Biotech 5: 212 doi: 10.4172/21559821.1000212

Page 9 of 9

34. Teng D, Wang JH, Fan Y, Yang YL, Tian ZG, et al. (2006) Cloning of beta-1,31,4-glucanase gene from Bacillus licheniformis EGW039 (CGMCC 0635) and its expression in Escherichia coli BL21 (DE3). Appl Microbiol Biotechnol 72 705-712.

35. Veith B, Herzberg C, Steckel S, Feesche J, Maurer KH, et al. (2004) The complete genome sequence of Bacillus licheniformis DSM13, an organism with great industrial potential. J Mol Microbiol Biotechnol 7: 204-211.

36. Waldeck J, Daum G, Bisping B, Meinhardt F (2006) Isolation and molecular characterisation of chitinase deficient Bacillus licheniformis strains capable of deproteinization of shrimp shell waste to obtain highly viscous chitin. App Environ Microbiol 72: 7879-7885.

37. Zhang H, Sang Q, Zhang W (2012) Statistical optimization of cellulases production by Aspergillus niger HQ-1 in solid-state fermentation and partial enzymatic characterization of cellulases on hydrolyzing chitosan. Ann Microbiol 62: $629-645$

38. Aygan A, Arikan B (2008) A new halo-alkaliphilic, thermostable endoglucanase from moderately halophilic Bacillus sp.C14 isolated from Van Soda Lake. Int J Agri Biol 10: 369-374

39. Aygan A, Karcioglu L, Arikan B (2011) Alkaline thermostable and halophilic endoglucanase from Bacillus licheniformisC108. Afr J Biotechnol 10: 789-796.

40. Miller GL (1959) Use of dinitrosalicylic acid reagent for determination of reducing sugar. Anal Chem 31: 426-428.

41. Sambrook J, Maniatis T (1989) Molecular cloning: a laboratory manual, 2nd edition. Cold Spring Harbor Laboratory Press, New York, USA.

42. Dave BR, Sudhir AP, Parmar P, Pathak S, Raykundaliya DP, et al. (2013) Enhancement of cellulose activity by a new strain of Thermoascus aurantiacus: Optimisation by statistical design response surface methodology. Biocatal Agr Biotechnol 2: 108-115.

43. Chapla D, Divecha J, Madamwar D, Shah A (2010) Utilization of agro-industria waste for xylanase production by Aspergillus foetidus MTCC 4898 under solid state fermentation and its application in saccharification. Biochem Eng J 49: 361-369.

44. Acharya BK, Mohana S, Jog R, Divecha J, Madamwar D (2010) Utilization of anaerobically treated distillery spent wash for production of cellulases under solid-state fermentation. J Environ Manage 91: 2019-2027.

45. Jeya M, Zhang YW, Kim IW, Lee JK (2009) Enhanced saccharification of alkalitreated rice straw by cellulase from Trametes hirsuta and statistical optimization of hydrolysis conditions by RSM. Bioresour Technol 100: 5155-5161.

46. Mohana S, Shah A, Divecha J, Madamwar D (2008) Xylanase production by Burkholderia sp. DMAX strain under solid state fermentation using distillery spent wash. Bioresour Technol 99: 7553-7564

47. Johnvesly B, Naik GR (2001) Studies on production of thermostable alkaline protease from thermophilic and alkaliphilic Bacillus sp. JB-99 in a chemically defined medium. Proc Biochem 37: 139-144

48. Singh J, Batra N, Sobti RC (2001) A highly thermostable, alkaline CMCase produced by a newly isolated Bacillus sp. VG1. World Journal of Microbiol Biotechnol 17: 761-765.

49. Hakamada Y, Endo K, Takizawa S, Kobayashi T, Shirai T, et al. (2002) Enzymatic properties, crystallization and deduced amino acid sequence of an alkaline endoglucanase from Bacillus circulans. Biochimica Biophy Acta 1570: 174-180.

50. Kim JY, Hur SH, Hong JH (2005) Purification and characterization of an alkaline cellulase from a newly isolated alkalophilic Bacillus sp. HSH-810. Biotechnol Lett 27: 313-316.

51. Raimbauh M, Alazard D (1980) Culture method to study fungal growth in solid fermentation. Eur J Appl Microbiol Biotechnol 9: 199-209.

52. Narahara H, Koyama Y, Yoshida T, Pichangkura S, Ueda R, et al. (1982 Growth and enzyme production in a solid-state culture of Aspergillus oryzae. Ferment Technol 60: 311-319.

53. Feniksova RV, Tikhomirova AS, Rakheleeva EE (1960) Conditions of amylase and proteinase formation in a surface culture of Bacillus subtilis. Mikrobiologiia 29: 745-748.

54. Xavier S, Lonsane BK (1994) Factors influencing fungal degradation of tota soluble carbohydrates in sugarcane-press mud under solid state fermentation. Proc Biochem 16: 435-440.

55. Lonsane BK, Ghidyal NP, Budiatman S, Ramakrishna SV (1985) Engineering aspects of solid state fermentation. Enzyme Microb Technol 7: 258-265.

56. Fukumori F, Sashihara N, Kudo T, Horikoshi K (1986) Nucleotide sequences of two cellulase genes from alkalophilic Bacillus sp. strain N-4 and their strong homology. J Bacteriol 168: 479-485

57. Sumitomo N, Ozaki K, Kawai S, Ito S (1992) Nucleotide sequence of the gene for an alkaline endoglucanase from an alkalophilic Bacillus and its expression in Escherichia coli and Bacillus subtilis. Biosci Biotechnol Biochem 56: 872-877.

58. Sánchez-Torres J, Pérez P, Santamaría RI (1996) A cellulase gene from a new alkalophilic Bacillus sp. (strain N186-1). Its cloning, nucleotide sequence and expression in Escherichia coli. Appl Microbiol Biotechnol 46: 149-155.

59. Ozaki K, Shikata S, Kawai S, Ito S, Okamoto K (1990) Molecular cloning and nucleotide sequence of a gene for alkaline cellulase from Bacillus sp. KSM635. J Gen Microbiol 136: 1327-1334

60. Jung KH, Chun YC, Lee JC, Kim JH, Yoon KH (1996) Cloning and expression of a Bacillus sp. 79-23 cellulase gene. Biotechnol Lett 18: 1077-1082.

61. Sonenshein AL, Hoch JA, Losick R (1993) Bacillus subtilis and Other Gram-Positive Bacteria: Biochemistry, Physiology and Molecular Genetics. Washington DC. American Society for Microbiology 3-16 pages. 